\title{
Preliminary study on in-situ Sludge Reduction technology in the northwest arid areas expressway service area
}

\author{
Zhao Jing ${ }^{1,2 *}$, Shao Shegang ${ }^{1,2}$, Jiang haifeng ${ }^{1,2}$ and Wang Xiao ${ }^{1,2}$ \\ ${ }^{1}$ Research Institute of Highway Ministry of Transport, Bei jing, 100088, China \\ ${ }^{2}$ Key Laboratory of Environmental Protection Technology on Road Traffic, Ministry of Transport, PRC, Bei jing, 100088, China
}

\begin{abstract}
High-speed service area in the northwest arid areas as the research object, through on-the-spot investigation, sludge and solid waste within the northwest service types, quantity and so on various aspects of information are collected, on the basis of research on sludge reduction technology in situ service areas, to improve the improve the level of expressway service area of the country's solid waste treatment practice experience.
\end{abstract}

\section{Introduction}

Economic and social development, transportation first. The transportation industry undertakes the responsibility and mission of development vanguard. On the basis of vigorously promoting the construction of comprehensive transportation, smart transportation, green transportation and safe transportation, the report of the 19th National Congress clearly proposes to strive to move forward into a "transportation power" and give priority to the development of green transportation. In 2016, the Highway Bureau of the Ministry of Transport officially issued the Guiding Opinions on the Implementation of Green Highway Construction, which clearly pointed out that the construction of green service areas should be promoted and the functions of highway tourism should be expanded. Green service area construction should be carried out in the design process, should strengthen the service area building energy-saving design, promote building insulation, clean energy, renewable energy, energy-saving ventilation and natural lighting and other technologies. In the process of operation, it is necessary to comprehensively promote the implementation of sewage treatment and utilization in the service area, promote water recycling technology, and realize the rational utilization of water. Actively promote the service area waste recycling technology, garbage classification collection and harmless treatment.

Then expressway service area as specifically for passengers and drivers stay resting place, the service area of solid waste mainly divided into the septic tank sludge and sewage treatment facilities of activated sludge, eat hutch garbage, garden waste and life rubbish [1], more than the vast majority of garbage will be organic pollutants (pops), can be good biochemical process. The biochemical treatment of solid waste can be divided into aerobic and anaerobic. This paper mainly chooses the aerobic treatment technology of solid waste. In the high-speed service area, the amount of kitchen garbage and household garbage is relatively small, and the amount of feces and activated sludge is relatively large. In the northwest arid region studied in this paper, the amount of garden wastes in the service area is also very small. The present situation of sludge and activated sludge treatment requires external transport treatment. Due to the large area and sparsely populated area in northwest arid region, most high-speed service areas are far away from urban and rural areas, the cost of external transport of sludge is high. At the same time, a small amount of kitchen waste and garden waste in the service area can also be considered for collaborative treatment with sludge [2]. So this article mainly through to the northwest arid areas of expressway service area field investigation and research, analysis of the current service area is given priority to with fecal pollution of organic pollutants in the operation of the existing problems in the processing, and provide services in sludge in situ reduction, harmless and recycling treatment of reasonable advice, and at the same time considering the reuse of sludge treatment, the maximum to save resources, protect the environment and reduce pollution, the application of the concept of green environmental protection to highway service area of the solid waste treatment technology, realizing the service area of the green environmental protection and energy saving, finally realizes the human and the nature coordinated and sustainable development.

\footnotetext{
"Corresponding author's e-mail: 332446199@qq.com
} 


\section{Survey of northwest Expressway service area}

\subsection{Research scheme}

This survey mainly focused on the expressway service areas in arid northwest China, including Gansu, Qinghai, Inner Mongolia and Ningxia, covering a number of expressways including Beijing-Tibet, Beijing-New And Lianhuo, and a total of 14 service areas.

The sources of information data are mainly field research, expert consultation, network data, statistical yearbook, government documents and other information.By investigating service area of traffic, traffic, discharge of sewage and wastewater treatment process, calculate the sewage treatment facility sludge, septic tank sludge production volume of the service area. Through direct dialogue with relevant leaders and staff of the service area and site visit, the production, collection and transportation mode and final destination of organic solid wastes such as activated sludge, dung, kitchen waste, household waste and garden waste were investigated.

\subsection{Analysis of survey results}

\subsubsection{Production of mucilage}

Sources of waste treatment is the basic service area of toilet septic tanks, fecal sludge production quantity per person a day to take $0.4 \mathrm{~kg} / \mathrm{day}$, sludge concentration coefficient according to 0.8 meter, sludge reduction coefficient of fermentation by 0.9 meter, dung sucking in manure rate according to the 2 meter, slag inclusion coefficient according to 1.01 meter, therefore, service area septic tank sludge processing scale according to 0.6 $\mathrm{kg} /$ day; Kitchen waste is $0.15-0.3 \mathrm{~kg} /$ day, and garden waste is $30-50 \mathrm{~kg} /$ day per hectare of green space.

According to the field survey data, the output of dung mud is basically equivalent to the theoretical data, while the output of kitchen waste and garden waste is slightly lower, and the lower limit is taken.

\subsubsection{Analysis of survey results}

- Sample test data

For the test data of the three groups of feces sludge samples, the average value is shown in Table 1.

Table 1. Septic tank muck detection data

\begin{tabular}{cccc}
\hline project & Refers to the standard & project & Refers to the standard \\
\hline Moisture content $(\%)$ & 98.5 & Nitrogen $(\mathrm{mg} / \mathrm{L})$ & 5330 \\
PH & 7.4 & Phosphorus $(\mathrm{mg} / \mathrm{L})$ & 870 \\
$\mathrm{SS}(\mathrm{mg} / \mathrm{L})$ & 13550 & Potassium $(\mathrm{mg} / \mathrm{L})$ & 1830 \\
$\mathrm{COD}(\mathrm{mg} / \mathrm{L})$ & 26730 & Total number of bacteria & 108 \\
$\mathrm{BOD}(\mathrm{mg} / \mathrm{L})$ & 14300 & Fecal coliform $(1 / \mathrm{mL})$ & 107 \\
$\mathrm{Cl}-(\mathrm{mg} / \mathrm{L})$ & 5200 & Parasitic worm eggs $(1$ & 80 \\
\end{tabular}

For the test data of three groups of kitchen waste samples, the average value is shown in Table 2.

Table 2. Kitchen waste detection data

\begin{tabular}{cccc}
\hline project & indicators & project & indicators \\
\hline Moisture content (\%) & 79 & Oil content (mg/L) & 6000 \\
Dry matter (\%) & 21 & Calcium (\%) & 0.5 \\
Crude protein (\%) & 16 & Sodium (\%) & 0.6 \\
Crude fiber (\%) & 3.5 & Crude fat (\%) & 7.1 \\
\hline
\end{tabular}

The technical parameters of garden waste are greatly influenced by space and time, and the general moisture content is calculated as $50 \%-80 \%$.

- Deal with the technical status and economic analysis

Because it is located in the high-speed service area in the arid region of northwest China, the average daily passenger flow varies greatly. On the whole, compared with the inland high-speed service area, especially in coastal cities, the passenger flow is less, and the sewage, household garbage and kitchen garbage are less. Among them, the restaurant kitchen garbage accounts for about $5-10 \%$ of the total household garbage in the service area. After the toilet sewage enters the septic tank, most service areas will hand over the muck and sewage together to the professional transportation company for external transportation. Some service areas also set up sewage treatment facilities, which adopt " $\mathrm{A}^{2} \mathrm{O}+\mathrm{MBR}$ "membrane treatment integration, sewage treatment 
capacity up to 100 tons/day, the effluent can reach the level ii or above, the park green for self-use.

In general, the concentration of solid waste, large-scale processing, resource utilization is higher, however for expressway service area is located in the remote, the transportation distance is determined by the in situ treatment technology more according to economy, for example, a high-speed service area in ningxia province, average daily traffic, 4000, 6000 peak traffic, sludge after septic tanks first, after entering the sewage treatment system. The sewage sludge of septic tank is shipped out 100 tons per year, and the cost is 28,000 yuan. Every year, 10 15 times, 8-15 cubic meters of garden waste are transported out of the country, with an annual cost of 200,000 yuan. Therefore, it is necessary to establish an on-site treatment facility for septic tank muck in a similar service area that is far away from the town and has a large amount of manure and garden waste. It can realize economic benefits as well as environmental protection benefits and social benefits to the greatest extent.

\section{Technical route of on-site disposal of manure and mud}

After the sewage of the toilet in the high-speed service area is treated by the septic tank, the excrement mud is regularly pumped to the dehydration equipment. The dehydrated liquid and the supernatant of the septic tank are all put into the sewage regulating tank. After the integrated sewage treatment equipment, the standard discharge or the service area flushing, greening and other recycling; The garden waste in the dehydrated solid residue mixed service area can be composted for self-use [3], or the organic solid waste in the service area can be further processed by the professional fertilizer company to realize resource utilization.

Among the above process routes, septic tank is a commonly used three-column septic tank process. Composting process is adapted to local conditions with relatively small technical difficulty, so the selection of dehydration equipment and technical parameters is particularly important [4].

\section{Research on the selection of dehydration equipment}

At present, the commonly used dewatering equipment of fecal mud include high pressure plate and frame dehydrator, spiral dehydrator and centrifugal dehydrator. The characteristics of the above three mechanical dehydration processes are compared in Table 3[5].

Table 3. Sludge mechanical dewatering process comparison table

\begin{tabular}{cccc}
\hline $\begin{array}{c}\text { The } \\
\text { dehydration } \\
\text { process }\end{array}$ & $\begin{array}{c}\text { Plate and frame } \\
\text { filter press }\end{array}$ & $\begin{array}{c}\text { The } \\
\text { centrifuge }\end{array}$ & $\begin{array}{c}\text { Screw } \\
\text { dehydrator }\end{array}$ \\
\hline Moisture & Less than $97 \%$ & $95 \% \sim$ & $95 \% \sim$
\end{tabular}

\begin{tabular}{|c|c|c|c|}
\hline content of mud & & $99.5 \%$ & $99.5 \%$ \\
\hline $\begin{array}{l}\text { Scope of } \\
\text { application }\end{array}$ & $\begin{array}{l}\text { Need to reduce } \\
\text { transportation, } \\
\text { drying or } \\
\text { incineration } \\
\text { costs; Further } \\
\text { reduction of } \\
\text { moisture } \\
\text { content }\end{array}$ & $\begin{array}{l}\text { Wide } \\
\text { application } \\
\text { range, } \\
\text { suitable for } \\
\text { small } \\
\text { viscosity, } \\
\text { density } \\
\text { difference } \\
\text { between } \\
\text { solid and } \\
\text { liquid } \\
\text { separation }\end{array}$ & $\begin{array}{l}\text { Not suitable } \\
\text { for inorganic } \\
\text { sludge (such } \\
\text { as metal } \\
\text { sludge) }\end{array}$ \\
\hline $\begin{array}{l}\text { Running } \\
\text { stability }\end{array}$ & $\begin{array}{l}\text { Easy jam; } \\
\text { Intermittent } \\
\text { operation }\end{array}$ & $\begin{array}{c}\text { Stable } \\
\text { operation; It } \\
\text { can run } \\
\text { continuousl } \\
\text { y }\end{array}$ & $\begin{array}{c}\text { Can realize } \\
\text { self-cleaning } \\
\text {, sustainable } \\
\text { operation }\end{array}$ \\
\hline $\begin{array}{c}\text { Operation } \\
\text { management }\end{array}$ & $\begin{array}{l}\text { The filter cloth } \\
\text { should be } \\
\text { cleaned and } \\
\text { replaced } \\
\text { regularly. } \\
\text { Complex } \\
\text { maintenance } \\
\text { and } \\
\text { time-consumin } \\
\text { g operation }\end{array}$ & $\begin{array}{l}\text { The } \\
\text { operation } \\
\text { and } \\
\text { maintenance } \\
\text { are } \\
\text { relatively } \\
\text { complex } \\
\text { and the } \\
\text { operation is } \\
\text { changeable }\end{array}$ & $\begin{array}{c}\text { Simple } \\
\text { maintenance, } \\
\text { short } \\
\text { operation } \\
\text { time }\end{array}$ \\
\hline $\begin{array}{c}\text { Covers an area } \\
\text { of }\end{array}$ & big & smaller & smaller \\
\hline Rinse water & large & less & little \\
\hline $\begin{array}{l}\text { Comprehensiv } \\
\text { e cost }\end{array}$ & higher & high & low \\
\hline
\end{tabular}

The plate and frame dehydrator is operated on the bracket alternately through the filter plate, the filter cloth and the filter frame. In the closed state, the sludge driven by the high-pressure pump is extruded by the plate and frame, so that the water in the sludge is discharged through the filter cloth, so as to achieve the purpose of dehydration. The plate and frame dehydrator has a large processing capacity, especially suitable for the dehydration of inorganic sludge, mud cake moisture content is relatively low, can reach 60\%; The disadvantage is that it is easy to block and requires the use of high pressure pump, which is not suitable for the dehydration of oily sludge. In addition, the intermittent operation cannot be continuous and automatic operation. Moreover, the press cloth in operation needs to be cleaned and replaced frequently, which increases labor cost and takes time and effort. It is suitable for large amount of sludge, such as sand sludge, mining industry, etc.

Centrifugal dehydrator is mainly composed of a transfer and a spiral conveyor with a hollow shaft. After the sludge is fed into the cylinder by the hollow shaft, it is immediately thrown into the rotary chamber under the centrifugal force generated by high-speed rotation. 
Centrifugal dehydrator Less investment in capital construction, less floor space, compact equipment structure, less dosage, large treatment capacity and good effect, moisture content of solid residue after dehydration is about $70 \%$, low total treatment cost, high degree of automation, simple operation, sanitation; The disadvantage is that the power consumption is large, the sludge contains gravel, easy to wear equipment has certain noise. In addition, the change of material concentration requires timely adjustment of speed and speed difference. In the high speed operating environment, the site is relatively dirty and muddy fog is generated. Improper operation is the occurrence of mud mouth blockage, backwashing with the possibility of mud re-slurry, at the same time, the centrifugal dewaterer by sludge load fluctuation is greater, higher quality requirements for the operators, so the current sewage treatment plant centrifugal dewatering process is less cases.

The screw type sludge dehydrator is composed of a fixed ring and a moving ring, and the spiral axis runs through the filter body. The filtrate is discharged from the filter joints formed by the fixed ring and the movable ring, and the mud cake is discharged from the end of the dewatering section. Fold screw machine is designed according to the filter press and upgrade the product, the moisture content of the solid residue after dehydration is around $80 \%$, the machine speed slow, energy saving energy saving, no noise and little vibration, bring their own spray device, less water consumption, not easy jam, low concentration of sludge dehydration directly, to achieve automatic control, can be unattended 24 hours, no secondary pollution, sealing equipment, odor non-proliferation, good running environment; The disadvantage is that it is not good at dewatering the sludge with large particles and large hardness, and the handling capacity is small.

As the sludge in the high-speed service area is mainly organic sludge, the sludge production is small, and the grease in the kitchen garbage may be mixed into the sludge, therefore, in summary, the choice of the dehydrator is more appropriate.

\section{5 conclusions and suggestions}

This paper Suggestions aiming at the characteristics of arid northwest arid areas, sparsely populated, advice service area sewage part adopts " $\mathrm{A}^{2} \mathrm{O}+\mathrm{MBR}$ " membrane process integration", the effluent can reach the secondary standard and above level, park greening for self-use, septic tank sludge and activated sludge, eat hutch garbage can adopt folded spiral dryer dehydration, dehydration after solid slag and garden waste compost, realizing the service area of pollutants outside or at the side of a small amount of as much as possible to reduce pollution to the environment, reduce the transportation cost.

Service as an important part of the highway, the highway as a foreign service window, in the long distance travel service plays an increasingly important role, is the main place to passengers and drivers stop to rest, in service of sludge and other organic solid waste treatment and level, directly related to the implementation of the green road and wisdom road concept, it is recommended that in the appropriate service area can consider to use septic tank sludge, eat hutch garbage and garden waste coordination treatment technology, achieve good economic benefits, environmental benefits and social benefits at the same time, create more remarkable characteristics, people experience a better service.

\section{Acknowledgement}

Special funds for basic scientific research operating expenses of public research institutes at the central level (2019-0120)

\section{References:}

1. Chen Songyan, editor-in-chief, Entering the World of Transportation, Shandong Science and Technology Press, October, 2013.

2. Bai Jing, Shen Hongyan, Dong Shikui, Zhang Guoxia, Cao Genhua. Ecological Utilization and treatment of highway green waste $[\mathrm{J}]$. Anhui agricultural science, 2010, 38(34): 19488-19490.

3. Li Sheng, Zhao Shengdun, Jia Liangxiao, Duan Liuxi. Theory and process rationality of aerobic fermentation of organic fertilizer. Modern Agricultural Science and Technology, 2014, 16: 186-188.

4. Zhang Chen, Ed., sludge treatment and disposal technology and engineering examples, 2006.4.

5. Chen Dandan, DouYuHao, Lu Ping, Huang Yaji, Zhou Jun. Research progress of advanced sludge dewatering technology, 2019, 38(10): 4722-4746. 